\title{
Exploring Possibilities of Potato Cultivation in Rice-Fallow of Sikkim
}

\author{
MANOJ KUMAR $^{1 *}$, RAGHAVENDRA SINGH $^{2,3}$, R K AVASTHE $^{2}$, J K SINGH ${ }^{1}$, P K PATHAK ${ }^{1}$ AND BINA TAMANG $^{1}$
}

\begin{abstract}
Frontline demonstration on potato (Kufri Sindhuri) was conducted by Krishi Vigyan Kendra, East Sikkim, India. A total 158 nos. of demonstration were conducted in rice-fallow (farmers' practice) at farmer's field in nine numbers of villages during the year 2019-20. Results revealed that average yield of rice and potato recorded was $2.09 \mathrm{t} / \mathrm{ha}$ and $14.13 \mathrm{t} / \mathrm{ha}$, respectively. Higher system rice equivalent yield (REY) was recorded $16.22 \mathrm{t} /$ ha in rice-potato and 2.1 $\mathrm{t} / \mathrm{ha}$ and rice-fallow system. System production efficiency (SPE) was also higher in rice-potato $(62.14 \mathrm{~kg} / \mathrm{ha} /$ day) as compared to rice-fallow $(14.51 \mathrm{~kg} / \mathrm{ha} /$ day). Land use efficiency (LUE) was recorded $71.51 \%$ and $39.45 \%$ in rice-potato and rice-fallow system, respectively. Net return was found Rs.16032/ha in rice-fallow and Rs.183952/- with rice-potato system during the years of demonstration. Higher benefit to cost (B: C) ratio was found 2.82:1 in rice-potato than in rice-fallow (1.62:1) system. Economic efficiency was also recorded higher in rice-potato (704.80 Rs/ha/day) than rice-fallow (111.33 Rs/ha/day) during the demonstrated year. Hence, it may be concluded that the inclusion of potato in rice -fallow is an option for increasing the additional income of the farmers for their livelihood improvement.
\end{abstract}

KEYWORDS

Economics, Farmers practice, Frontline demonstration, Rice equivalent yield

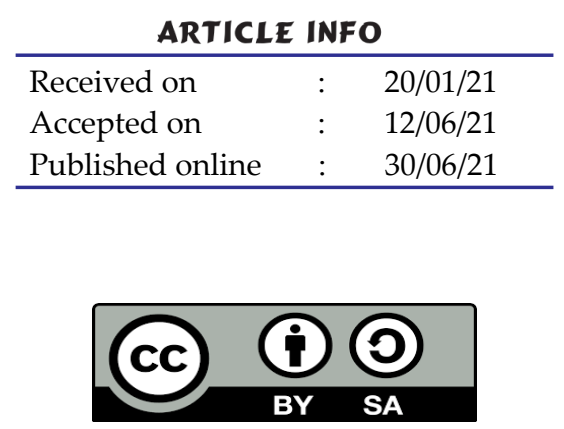

\section{INTRODUCTION}

$\mathrm{R}$ ice is the second most important cereal grown in the Sikkim after maize, which covered an area of 10481 ha with a productivity $1856 \mathrm{~kg} / \mathrm{ha}$, However in India rice is leading staple crop (Singh et al, 2017). The cropping intensity of the state is very low $(118 \%)$ due to mono cropping of rice (Avasthe et al, 2019). Therefore, crop diversification is recognized as an effective strategy for achieving the objectives of food and nutritional security, poverty alleviation, employment generation, judicious use of resources and sustainable agricultural development after harvesting of rice crop. Inclusion of pulses/oilseeds and vegetables in cropping system is more beneficial compared to monocropping for achieving the sustainable food and nutritional security (Kumar et al, 2016). Growing of winter crops (carrot, potato, potato, tomato, French bean, pea and lentil) after rice harvest increases the incomes of rural poor's (Kumar et al, 2014). Farmers' kept their land fallow after harvesting of rice during winter season, but the region receives rainfall up to end of mid-October or even in the month of January some times. There is sufficient residual soil moisture in crop fields even after harvest of paddy to growing the succeeding winter crops. Thus, there is potential for growing of potato on residual soil moistures, which increases the cropping intensity in the State.

Potato (Solanum tuberosum) is widely known as 'poor man's friend' owing to its potential to supply low cost energy contin- uously and high nutrition to the people. In Sikkim, area under potato cultivation is about $19.14(000)$ ha with the production to the tune of 89.91 (000) tonnes and productivity of about 4.70 tonnes per ha (Horticulture at a glance, 2018). Productivity is less due to cultivation of traditional variety and susceptible of insect and pest. Kufri Sindhuri is a high yielding late maturing variety (120-140 days), medium sized red colored tubers, round/elliptical in shape with deep eyes. This variety is resistant to early blight and leaf rot diseases with minimal irrigation. This variety showed good performance in other part of hill region. Hence, it is decided to introduce the potato in ricefallow to utilize the residual soil moisture in East District of Sikkim. Therefore, Krishi Vigyan Kendra, East Sikkim took an initiative and conducted the frontline demonstration programme on potato during the year 2019-2020 in rice-fallow for getting the additional income of the farmers and increase the cropping intensity in the East District of Sikkim.

\section{MATERIALS AND METHODS}

Krishi Vigyan Kendra, East Sikkim, Ranipool conducted Frontline Demonstrations (FLDs) on potato cultivation in ricefallow under rice-based system of Sikkim at farmers field during winter season of 2019-20 in different village viz., Nandok, Timpyem, Sajong, Lingtam, Thanka-martam, Saurini, Pachykhani, Amba and Lossing etc. of East District. The total rainfall received during cropping period was $159.0 \mathrm{~mm}$ (Fig. 1). Average maximum and minimum temperature recorded were $18.5^{\circ} \mathrm{C}$ and $9.6^{\circ} \mathrm{C}$, respectively during the crop-

\footnotetext{
1 Krishi Vigyan Kendra, East Sikkim, Ranipool, Sikkim, India

2 ICAR-National Organic Farming Research Institute, Tadong, Sikkim, India, Sikkim, Tadong, India

3 ICAR-Indian Institute of Pulse Research, Kanpur, india

*Corresponding author email: mkumar_cprs@yahoo.co.in
} 
ping period. Maximum temperature recorded was $22.93^{\circ} \mathrm{C}$ in the month of November, 2019 while the minimum temperature recorded was $6.7^{0} \mathrm{C}$ during January 2020 (Fig. 1) Field was ploughed after harvesting of rice with the help of bullock to fine seed bed for good tuberization of potato crop and field was leveled. The row was made with the help of spade in a distance of $60 \mathrm{~cm}$ and after that FYM @ 13-17 t/ha was applied in the row. Medium size tubers (40-50 g) were placed in the row with spacing of $20 \mathrm{~cm}$ between the tubers. Weeding was done after 30 days of germination and field was kept weed-free up to 60 days for better tuberization. One-time life saving irrigation was given if necessary, for better yield. The crop was harvested after 110-125 days of planting.

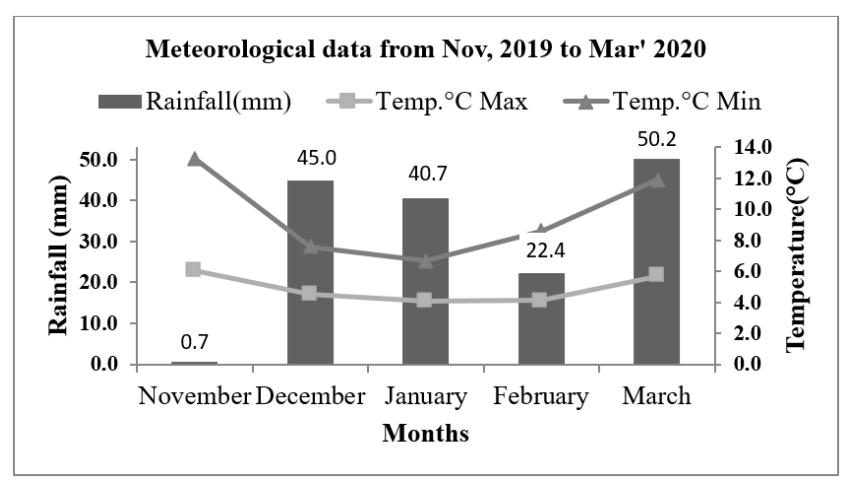

Fig. 1: Rainfall and temperature during the cropping period

Initially, training-cum-demonstration programme on potato cultivation was organized in nine nos. of villages. A farmer from all the villages learnt about the technology and volunteered to bring about 4.8 ha of land under potato cultivation after rice harvest during the year 2019-20 covering 158 nos. of farmers. Previously they followed mono-cropping system of rice cultivation while the land remained fallow after the harvest of Kharif rice. Regular monitoring of the demonstration site was made by Subject Matter Specialists through regular visits and provided proper advisories. Potato yield was recorded on demonstration basis and converted into $t / h a$.

Rice equivalent yield (REY) was estimated using formula: $\mathrm{REY}=$ yield of rice (first crop) + yield of second crop $\mathrm{x}$ price of second crop/price of rice. Land use efficiency (LUE) was obtained by dividing total number of days occupied by different crops by 365 days and multiplying with 100. System production efficiency $(\mathrm{kg} / \mathrm{ha} /$ day) was calculated by dividing production of sequence by 365 days and system economic efficiency $(\mathrm{kg} / \mathrm{ha} /$ day) was obtained by net returns of the sequence divided by total duration of crop sequences (Kumar et al., 2019a).

Yield data from the demonstration and farmers practice were recorded and their technology gap, extension gap and the technology index were worked out using methods developed by Kumar et al (2014) as stated below:

Technology gap = Potential yield - Demonstration yield

Technology Index = (Potential yield- Demonstration yield $)$ / Potential yield

In economics, cost of cultivation was taken into account for calculating economics of treatments to work out net return per ha and benefit cost ration. The gross return was taken as total income earned from produce of tuber yield based on prevailing price. Net return and benefit to cost ratio was calculated with the help of following formula (Kumar et al, 2016). Net return $(\mathrm{Rs} / \mathrm{ha})=$ Gross return $($ Rs. /ha) - Cost of cultivation (Rs/ha)

Benefit : cost ratio $=($ Gross return $(\mathrm{Rs} / \mathrm{ha}) /$ Cost of cultivation (Rs/ha)

\section{RESULTS AND DISCUSSION}

\section{Productivity}

Mean rice yield recorded was $2.09 \mathrm{t} /$ ha under rice-fallow and rice potato cropping system. Potato yield was ranged 12.4$23.0 \mathrm{t} / \mathrm{ha}$ in different villages with average productivity 14.13 $\mathrm{t} /$ ha in the demonstrated year (Table 1). Rice equivalent yield (REY) of potato yield was recorded $14.13 \mathrm{t} / \mathrm{ha}$. Higher system REY was recorded $16.2 \mathrm{t} / \mathrm{ha}$ in rice-potato system than $2.09 \mathrm{t} / \mathrm{ha}$ and rice-fallow (farmers practice). This might be due to introduction of second crop as potato in rice-fallow. System production efficiency (SPE) was also higher in rice-potato $(62.14 \mathrm{~kg} / \mathrm{ha} /$ day) than rice-fallow $(14.51 \mathrm{~kg} / \mathrm{ha} /$ day $)$. Maximum system REY was recorded with the inclusion of vegetables in rice-fallow (Kumar et al., 2019a). Mishra et al (2007) reported that higher productivity with inclusion of vegetables and pulses in rice-based cropping system. The same result was also reported by Kumar et al. (2019b) and Das et al. (2010) Das et al (2010).

Table 1: Rice yield, potato yield and rice equivalent yield of different system

\begin{tabular}{llllllll}
\hline $\begin{array}{l}\text { Cropping } \\
\text { system }\end{array}$ & $\begin{array}{l}\text { Area } \\
\text { (ha) }\end{array}$ & $\begin{array}{l}\text { Rice yield } \\
(\mathrm{t} / \mathrm{ha})\end{array}$ & $\begin{array}{l}\text { Potato yield } \\
(\mathrm{t} / \mathrm{ha})\end{array}$ & $\begin{array}{l}\text { System }{ }^{*} \text { REY } \\
(\mathrm{t} / \mathrm{ha})\end{array}$ & $\begin{array}{l}* * \text { SPE } \\
(\mathrm{kg} / \mathrm{ha} / \text { day })\end{array}$ & $\begin{array}{l}\text { Technology gap } \\
(\mathrm{t} / \mathrm{ha})\end{array}$ & $\begin{array}{l}\text { Technology } \\
\text { index }(\%)\end{array}$ \\
Rice-fallow & & 2.09 & - & 2.09 & 14.51 & 0.57 & 21.42 \\
Rice-potato & 4.80 & 2.09 & 14.13 & 16.22 & 62.14 & 5.77 & 26.22 \\
\hline
\end{tabular}

${ }^{*}$ REY: Rice equivalent yield, ${ }^{* * S P E}$ : System Production efficiency 

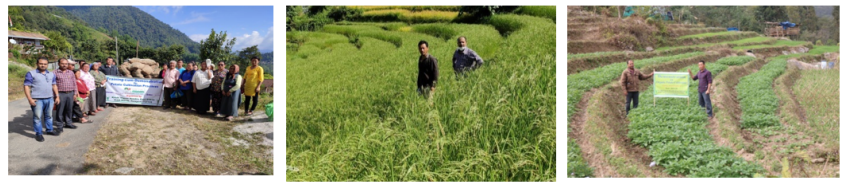

Distribution of potato seed

General view of rice and potato crop in the farmers field

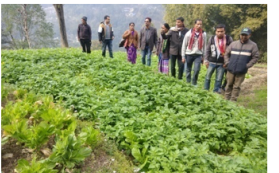

Assam official \& farmer visiting the potato field field

Fig. 2: Different activities during Frontline Demonstration

\section{Technology gap and index}

The technology gap was recorded $0.57 \mathrm{t} / \mathrm{ha}$ and $5.77 \mathrm{t} / \mathrm{ha}$ with rice-fallow and rice-potato respectively. The variation in technology gap observed might be due to dissimilarity in soil fertility, management and climatic factors. The technology index showed the feasibility of evolved technology at the farmer's fields. The lower value of technology index the more is the feasibility of technology (Kumar et al, 2014). The technology index was found 21.42 percent in rice-fallow and 26.22 percent with rice-potato system.

\section{Land use efficiency (LUE)}

The land use efficiency (LUE) recorded was $71.51 \%$ and 39.45 $\%$ in rice-potato and rice-fallow system, respectively. This was perhaps due to the inclusion of potato after rice harvest and land was utilized efficiently, which enhanced the profitability with more employment generation during the whole system. Kumar et al., (2017) reported intensification through short duration vegetables/ pulses in system increases LUE. This was also supported with the results of Kumar et al., (2019a). Sharma et al. (2004) Sharma et al (2004) has also reported that intensification of vegetables and legumes crops increase the LUE by $46.7-78.31 \%$.

\section{REFERENCES}

Avasthe RK, Singh YA and R 2019. Technological intervention in Organic farming for doubling farmers income - Sovenir cum Book pp. 05 (Tadong, Sikkim) .

Das A, Patel DP, Munda GC, Ghosh PK, Saha R, Kumar BJ and M. 2010. Productivity and soil nutrient balance sheet as influenced by in situ biomass recycling in rice-vegetable cropping sequences. Environment and Ecology 28(1):160-163.

Kumar M, Kumar R, Meena KL, Dj R and Kumar A. 2016. Productivity enhancement of rice through crop establishment techniques for livelihood improvement in Eastern Himalayas. Oryza 53(3):300-308.

Kumar R, Deka BC, Kumawat N and Ngachan SV. 2014. Effect of integrated nutrition, biofertilizers and zinc application on production potential and profitability of garden pea (Pisum
Table 2: Economics and land use efficiency of potato of different system

\begin{tabular}{|c|c|c|c|c|}
\hline $\begin{array}{l}\text { Cropping } \\
\text { system }\end{array}$ & $\begin{array}{l}\text { Net income } \\
\text { (Rs/ha) }\end{array}$ & $\begin{array}{l}\mathrm{B}: \mathrm{C} \\
\text { ratio }\end{array}$ & $\begin{array}{l}\text { **EE } \\
\text { (Rs/ha/day) }\end{array}$ & $\begin{array}{l}{ }^{* * *} \text { LUE } \\
(\%)\end{array}$ \\
\hline Rice-fallow & 16032 & 1.62 & 111.33 & 39.45 \\
\hline Rice-potato & 183952 & 2.82 & 704.80 & 71.51 \\
\hline
\end{tabular}

\section{Economics}

The input and output prices of commodities prevailing during the years of demonstration were taken for calculating cost of cultivation, gross return, net return, benefit to cost ratio (Table 2). Economic indicator clearly showed that net return from the rice-potato was substantially higher than the rice-fallow. Net return was Rs.16032/ha in rice-fallow, whereas it was Rs.183952/- in rice-potato system. The benefit to cost (B: C) ratio recorded was 1.62 and 2.82 in ricefallow and rice-potato system, respectively. Economic efficiency recorded was $111.33 \mathrm{Rs} / \mathrm{ha} /$ day under in rice-fallow and $704.80 \mathrm{Rs} / \mathrm{ha} /$ day rice-potato. Kumar et al., (2019a) reported increase in net profit over traditional system with the inclusion of vegetable crops in sequences.

\section{CONCLUSION}

Farmers was happy with the cultivation of potato variety Kufri Sindhuri by the principles of "learning by doing" and "seeing is believing". After successful implementation of the technology, farmers were highly impressed and motivated by the potato variety Kufri Sindhuri due to its cost effectiveness, higher net income and suitable for climatic condition of Sikkim due to resistant against disease and pest and also due to its taste. By adoption of Kufri Sindhuri in rice-fallow farmers can utilized the residual soil moisture, increase the productivity, increase the additional income and enhanced the cropping intensity.

sativumL.) in eastern Himalaya, India. Legume Research An International Journal 37(6):614-614. url: https://dx.doi.org/ 10.5958/0976-0571.2014.00685.7. doi: 10.5958/0976-0571.2014. 00685.7

Mishra MM, Nanda SS, Mohantys M, Kc P and Mishra SS 2007. Crop diversification under rice-based cropping system in western Orissa. In System F and Association D, Extended Summaries. 3rd National Symposium on Integrated Farming Systems.

Sharma RP, Pathak SK, Raman H and R K. 2004. Diversification of Traditional rice (Oryza sativa) - based cropping systems for sustainable production in South Bihar alluvials plain. Indian Journal of Agronomy 49(4):218-240.

Singh AK, Singh AK, Kumar R, Prakash V, Sundaram PK and Sk Y. 2017. Indian Cereals Saga: Standpoint and Way Forward. Journal of AgriSearch 4(1):1-10. 


\section{Citation:}

Kumar M, Singh R, Avasthe RK, Singh JK, Pathak PK and Tamang B. 2021. Exploring Possibilities of Potato Cultivation in Rice-Fallow of Sikkim . Journal of AgriSearch 8(2): 155-158 